ANNA SEREDYŃSKA

Forum Pedagogiczne

Wydział Pedagogiczny

Akademia Ignatianum

2018/1

Kraków

Wpłynęło: 05.09.2017

Zatwierdzono do druku: 31.03.2018 DOI: 10.21697/fp.2018.1.20

\title{
MOTIVATION OF HOSPICE VOLUNTEERS IN THE PAST AND TODAY
}

\begin{abstract}
The first hospices in Poland were opened in 1970s, however, the reasons why people decided to volunteer in such places in the past and why they do it today differ. The article presents the ideas governing hospice volunteering over forty years ago on the basis of an interview with Ewa Bodek, an ex-coordinator of voluntary service in St. Lazarus Hospice in Cracow. This interview is now being prepared for publication. Present volunteers' motivation is analysed on the basis of interviews with candidates for voluntary service in St. Lazarus Hospice in Cracow conducted during the last four recruitment processes. The novelty of the article lies in juxtaposition of qualitative research on motivation of the first hospice volunteers in Poland and the results of the analysis of the motivation of contemporary candidates for voluntary service in St. Lazarus Hospice in Cracow.
\end{abstract}

Key words: voluntary service, motivation, hospice.

\section{Introduction}

The history of hospice voluntary service in Poland is not long and dates back to the 1970s, when the first hospice was opened in Cracow. However, transformations which took place in Poland after 1989 led to changes in the motivation of people who decide to volunteer in such specific places as hospices. That is why it is worth comparing the incentives of the participants of a so called synodal group, who created St. Lazarus' Hospice in Cracow in 1970s, and the incentives of contemporary candidates for voluntary service in this Hospice.

\section{Volunteer movement and hospice voluntary service in Poland}

According to Piotr Krakowiak, a Pallotine, the foundations of the contemporary hospice movement are based on Christian and humanistic values (Krakowiak 2007, pp. 195-248) and the functioning of hospices is governed by ecumenical rules. 
The name 'hospice' was used already in the Middle Ages to describe hospitals and shelters for the sick and dying. The first hospice that resembled the ones known today was opened in 1967 in London by Cicely Saunders (Weber 2009, pp. 1315; Górecki 2010a; Górecki 2010b; Górecki 2013; Górecki 2016), who developed a contemporary model of hospice care. This kind of care belongs to broadly understood palliative care defined by Krystyna de Walden-Gałuszko as "a social movement involving doctors, nurses and non-medical carers who offer help on a voluntary basis" (de Walden-Gałuszko 2004, pp. 12-13; see Grudziński 2013). The name of this movement derives from a Latin word hospes denoting a person offering hospitality, which is significant, as in such understanding 'hospice' is not associated with a place but rather with people who offer the sick and dying hospitality of their hearts.

The first attempts to open a hospice in Poland were undertaken in 1971 by a synodal group operating at the Lord's Ark Church in Nowa Huta in Cracow (Górecki 2000, pp. 75-92). The first volunteers who worked in this hospice previously worked with dying patients in Stefan Żeromski Municipal Hospital in the isolation ward, whose head then was doctor Stanisław Kownacki, in the Helcels Welfare Home, and at patients' homes. Other hospices in Poland opened at that time were Pallotinum Hospice in Gdańsk and John Cantius Hospice in Poznań.

At the beginning hospice care was provided only by volunteers who even today constitute a large proportion of hospice teams. According to the Public Benefit and Volunteer Work Act (Ustawa o działalności pożytku publicznego i wolontariacie), a volunteer is a person who "voluntarily and without pay provides services as described in the Act” (Act 2003, art. 2). Jadwiga Przewłocka offers a more general definition of a volunteer: "a natural person who voluntarily and without pay provides services for non-government organizations, churches, social unions, organs of public administration and their subordinate units" (Przewłocka 2011, p. 7). Ewa Bodek's definition of voluntary service adds a new dimension to the understanding of this term, as, according to her, "first and foremost, voluntary service is about selflessness and freedom of choice" (Bodek 2009, p. 16). This definition replaces the understanding of voluntary service as an unpaid activity by a selfless activity, which can influence the motivation of candidates for voluntary service.

\section{Motivation of hospice volunteers}

The word motivation derives from a Latin word movere, which means 'movement' or 'setting in motion' (Gasiul 2002, p. 223). Thus, motivation is "a process aimed at changing a present situation into a situation which is more beneficial for a given individual [...]. On the one hand, motivation can be defined as a disposition to initiate, maintain and direct certain forms of behaviour [...], and, on the other hand, as a current process of activity directed at achieving more or less specified goals, which is accompanied by various emotions and which engages other forms of mental 
processes (e.g. reasoning, memory)" (Gasiul 2002, p. 223). Motivation of volunteers, on the one hand, triggers their activity connected with the commencement of work in a hospice, and, on the other hand, maintains this activity in difficult situations; the death of a patient can certainly be considered a difficult situation.

The results of studies on motivation of volunteers were published in J. Przewłocka's The report (Przewłocka 2011, pp. 7-18). According to these studies, volunteers are motivated by the following factors: it gives them pleasure ( $43 \%$ of respondents), they believe that if they help others, others will also help them (32\%), it is consistent with their values (29\%), they want to have contact with other people and spend time doing something useful (23\%), they want to acquire new skills (21\%), they do it for their friends (18\%), they were asked to do it and could not say 'no' (13\%), they have a debt to pay back (4\%), and they want to gain work experience (2\%).

Twenty years of experience in voluntary service allowed E. Bodek, an excoordinator of voluntary service in St. Lazarus' Hospice in Cracow, to claim that volunteers were driven by various types of motivation (Bodek 2009, pp. 16-21) including: loneliness, a sense of humility and a lack of values; a desire to run away from a difficult situation at home; complexes or a desire to shine, a wish to do great things or to boost one's self-esteem; having spare time; or simply a wish to do something for others out of gratitude for the gift of life.

Studies conducted among volunteers in Sweden revealed numerous types of motivation (Andersson et al. 2005, pp. 602-609), some of which were based on altruism, and some on self-actualization and self-affirmation. Studies on motivation of volunteers indicate that if motivation is divided into two types: self-directed and others-directed, the latter serves as an indicator whether a person is going to remain in voluntary service (Brown et al. 2012, pp. 87-96). It is also connected with greater satisfaction derived from voluntary work (Finkelstein 2008, pp. 9-18). Another study demonstrated that volunteers who strongly identify with moral norms are often driven by pro-social motivation, high ideals and orientation towards others (Winterich et al. 2013, pp. 759-770). For people who took voluntary care of the sick in Mexico spirituality was an important aspect in their motivation to volunteer (Silverberg Koerner et al. 2013, pp. 95-111). Spirituality turned out significant both for volunteers and their work and their abilities to offer support to a sick person. Another study revealed that motivation of volunteers depends on their age: the young wanted to maintain interpersonal relations, while the old wanted to serve others (Omoto et al. 2000, pp. 181-197).

\section{Motivation for hospice voluntary service in the past and today}

The first hospice in Poland, St. Lazarus' Hospice in Cracow, is one of numerous hospices operating in Poland today. At the beginning it was modelled on St. Christopher's Hospice in London, and only volunteers worked there. Although in modern hospices they work alongside paid doctors, nurses, cleaners and 
administrative workers, they still play a significant role, and that is why the factors that help them to continue their voluntary service and not to give up are very important.

\section{Research procedures}

The article is based on two different studies. In order to investigate the motivation of the first volunteers and their driving force, the author analysed the interview with an ex-coordinator of voluntary service in St. Lazarus' Hospice in Cracow, Ewa Bodek.

The interview, which was conducted between January and September 2014, is now being prepared for publication, and the whole interview will serve as a basis for a more extensive analysis in the future. The article is based on several fragments of the interview referring to the motivation of volunteers who created the first hospice in Poland. E. Bodek was a coordinator of the voluntary team in St. Lazarus' Hospice in Cracow between 1991 and 2012 and was personally engaged in recruiting volunteers. Her comments are based on documents she collected during individual interviews. Earlier she had done voluntary work within the structure of the Hospice at patients' homes. She stayed in touch with people who created St. Lazarus' Hospice and met the creators of St. Christopher's Hospice in London, which served as a model for the Hospice in Cracow. In the interview she managed to convey the atmosphere of the beginnings of the hospice movement in Poland.

The second study analysed the results of four recruitment processes conducted among 206 candidates for St. Lazarus Hospice in Cracow in the years 2012, 2013, 2014 and in winter 2015. The recruitment process allowed for selecting suitable volunteers and consisted of their filling in several forms and talking with a psychologist and a team coordinator. The article focuses on the fragments of the talks regarding candidates' motivation.

The aim of the article is to compare the changes in motivation of candidates for voluntary service today and forty years ago, at the very beginning of hospice movement in Poland. The novelty of the article lies in the presentation of the experience of the first Polish coordinator of a hospice volunteer team regarding their motivation. Her experience is of great value for hospices in Poland today, as it allows people working and serving in them to return 'to the sources' from which hospice practice originated.

The main research problem of the article is expressed by the question: What motivated people to embark on voluntary service at the beginning of the hospice movement and what motivates people to do it today? The detailed questions are directly derived from the main question:

- What motivated the first volunteers in St. Lazarus' Hospice in Cracow according to one of its creators? 
- What motivates contemporary candidates for voluntary service on the basis of interviews conducted with them in the years 2012-2015?

The motivation of volunteers and the number of years they worked in the Hospice (in the past and now) were chosen as variables. Motivation was examined in two ways, that is why their indicators are different: in the first study Ewa Bodek's opinions were the indicator, while in the second study this role was played by the candidates' statements recorded during interviews.

In the first study, the narrative method was the research method, and an unstructured interview was the technique, while in the second study a semistructured interview was the technique. The question opening the interview about people who created St. Lazarus' Hospice served as a research tool in the first study, a set of questions listed below served as a research tool in the second study:

- Why do you want to volunteer in the Hospice?

- What are you afraid of?

- What potential obstacles can you predict in your voluntary service?

During the interview these questions were elaborated on and additional ones were asked if necessary.

The types of motivation of candidates for voluntary service revealed during the interviews were assigned to the following seven categories:

- no particular reason to become a volunteer (e.g. I have a lot of time and want to do something with it) (o),

- loneliness (1),

- a desire to redress the harm done in the past or a regret that one has neglected to take proper care of a relative (2),

- searching for a welcoming environment (3),

- compensating for one's own problems, mostly personality problems (4),

- external motivation - being encouraged by someone else (5),

- values (6),

- a desire to do something more for others, in God's service (7).

Figure 1: Motivation of candidates for voluntary service in St. Lazarus Hospice in Cracow

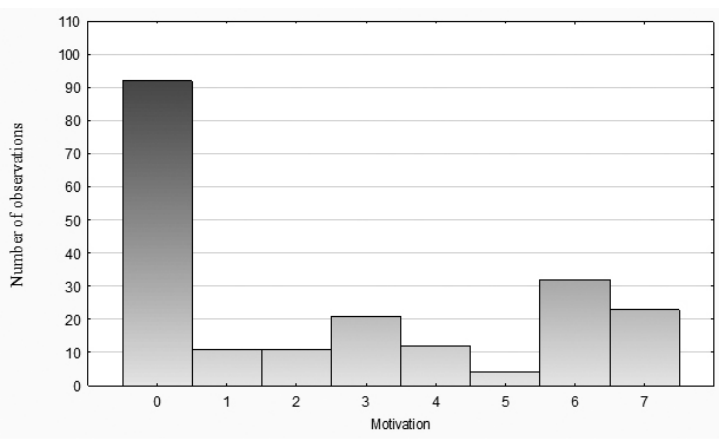

Source: own studies 


\section{Motivation of volunteers at the beginning of the hospice movement in Poland}

In order to understand motivation of the first hospice volunteers, it is necessary to gain an insight into their understanding of the nature of a hospice. This information can be found in the words uttered by Maria Leńczyk, one of the first doctors who worked in the Hospice (at the beginning everyone worked there for free, so their motivation was indeed motivation for voluntary service, regardless of the fact they were doctors, nurses or carers). E. Bodek said that it was about "the essence of a hospice, which Marysia called hospitality. Of course, I will not offer a sick person hospitality in my house, because I do not have a private nursing home. But this is hospitality of the heart, which can offer the same things except for a bed [...]. Now it is assumed that hospes is a building, but at the beginning it was not like that, it was about hospitality of one's heart." Talking about the Hospice building, E. Bodek used a similar image: "and that is why we call it home. Not a hospital, not a shelter, but St. Lazarus' home”. It can be said that volunteers had to engage themselves totally, as with such understanding of voluntary service it was not possible to offer only several hours of one's spare time. One had to be fully involved, somehow allowing another person to enter one's heart, opening unto him, and bearing in mind the pain connected with his/her departure.

A lot of inner strength was needed to cope with such duties, and for the first volunteers this strength was certainly of a spiritual nature. The founder of St. Lazarus' Hospice in Cracow, Father Józef Gorzelany, explained it to his first volunteers, as E. Bodek recalled, when he pointed at the hospice chapel and two wards directly behind it: "here we pray and here strength and force are granted, and there we go to serve with these hands. To share what we have been given here."

Motivation for voluntary service among the first volunteers in this Hospice also came from authenticity and from knowing that they could give themselves, give who they were. E. Bodek described doctor Krystyna Smolak, who taught work ethics, using the following words: "she was like this, very tactful, very delicate, very sensitive. Because she knew that this was the most important, that this was the first meeting with a human being [...]. She showed these ethical truths in herself." Later she talked about other hospice doctors, Jan Deszcz, Maria Leńczyk and Krystyna Smolak: "and apart from this, a human attitude. Something medical schools usually do not teach to future doctors. Yes, this interpersonal communication between a patient and a doctor. I saw it because I drove them to patients' homes and I saw these conversations, I witnessed these conversations. When they came inside, they sat as if they were visiting their closest family." Another founder of the Hospice, doctor Janina Kujawska, was described by E. Bodek the following way: "she could be scathing, witty, sarcastic while talking to us. She was like that, but it did not contradict the warmth and attention and concern in her, especially in situations when medicine could no longer help." 
Not only hospice doctors were described by E. Bodek in this manner, but also volunteers who took care of the sick, and who were, to some extent, the doctors' apprentices. According to her, when a volunteer Basia entered, "everything became so easy, so warm. Basia joined the prayer in the patients' families in such a natural way [...]. I think it was a secret of her authentic love for people. And she behaved in the way she wanted other people to behave towards her."

E. Bodek noticed a very strong link between motivation of the first volunteers and the style of work of the founders of St. Lazarus' Hospice in Cracow. She described these first volunteers, today already elderly persons, using the following words: "even when they cannot dress a wound, or their hands are shaking while bringing tea or food because of age, they still come, because they know, because they remember Marysia (doctor Leńczyk) at the bed. And they know how important it is. To be." This BE is probably a keyword. In such perception of voluntary service it is more important to be than to do something. This being by the patients' side can change the quality of their life.

Summing up, it can be concluded that motivation for undertaking voluntary service stemmed from the inside of the first volunteers and creators of St. Lazarus' Hospice in Cracow - it was internal, came from their convictions, upbringing and even their identity. It was connected with the belief that helping the weak and the sick is not something extraordinary, but a part of life, a natural duty. E. Bodek showed it when she described how she had joined the voluntary team: "Taking care of the sick was something obvious to me. To me it meant humanity. And Church. And Humanity, Jesus Christ, Church, God's law. And something obvious - that if I am strong, and someone is weaker than me and needs help, I am to help." These people probably did not consider themselves volunteers. They did not gain anything material by doing it. They just thought that it was their duty towards life.

\section{Motivation of volunteers today}

Today motivation of volunteers is apparently less straightforward. Firstly, it is connected with tangible benefits, such as additional points while applying to university, something to put in one's CV to enhance it, etc. Of course, it can be said that the first volunteers also benefited, e.g. derived personal satisfaction from their service. However, as it was presented above, voluntary service was not something unusual for them, they perceived it as fulfilling their duty. The data from the chart can be also presented in a table. The table presents different types of motivation of candidates to voluntary service from the period 2012-2015. Types of motivation revealed during interviews were clustered in the following seven categories described earlier. 
Table 1: Candidates' motivation for voluntary service in St. Lazarus' Hospice in Cracow

\begin{tabular}{|c|c|c|c|c|}
\hline $\begin{array}{c}\text { Category of } \\
\text { motivations }\end{array}$ & Number & $\begin{array}{c}\text { Cumulative } \\
\text { number }\end{array}$ & Percentage & $\begin{array}{c}\text { Cumulative } \\
\text { percentage }\end{array}$ \\
\hline 0 & 92 & 92 & 44,660 & 44,660 \\
\hline 1 & 11 & 103 & 5,339 & 50,000 \\
\hline 2 & 11 & 114 & 5,339 & 55,339 \\
\hline 3 & 21 & 135 & 10,194 & 65,534 \\
\hline 4 & 12 & 147 & 5,825 & 71,359 \\
\hline 5 & 4 & 151 & 1,941 & 73,301 \\
\hline 6 & 32 & 183 & 15,533 & 88,835 \\
\hline 7 & 23 & 206 & 11,165 & 100,000 \\
\hline
\end{tabular}

Source: own studies.

The data reveal that almost $45 \%$ of candidates are not motivated by a particular reason. Almost $30 \%$ of them are driven by external motivation or the need to compensate for their deficits. Only $15 \%$ of candidates want to become volunteers because of their values, and $11 \%$ of them want to do something more in their lives. The last two groups probably include persons who, like the first volunteers, consider helping others to be their duty, and not something exceptional. As the volunteers were verified within a few months and a year after beginning their voluntary service, one could see the correlation between the length of the service and their initial motivation. It is also important that the correlation between the length of remaining in voluntary service and selflessness of motivation (the types of motivation are ordered from the lack of motivation through external and self-directed motivation to internal and altruistic motivation) equals: Spearman's rho (both variables are qualitative and ordinal $)=0,65$, which is a statistically significant result $(\mathrm{p}>0,05)$.

Summing up, the results of the studies conducted in recent years can be compared with the assumptions made at the onset of the hospice movement in Poland. The people who created the first hospices were certainly aware of their motivations and desires, and they were totally dedicated to their work. Today not many volunteers are driven by such commitment, some do not even know what to expect from hospice service, and what they can and should offer as hospice volunteers.

\section{Discussion of the results}

As J. Przewłocka indicated in her report, $29 \%$ of voluntary workers decide to become volunteers because of the values they believe in (Przewłocka 2011, pp. 7-18). It can be said that this number corresponds to the results obtained in the study: about $26 \%$ of candidates wanted to volunteer because of values or because they wanted to do something good in life. The results of the study confirm E. Bodek's list of factors motivating volunteers based on the experience gained during 20 years of work as 
a team coordinator (Bodek 2009, pp. 16-21): loneliness, a sense of humiliation and the lack of values, an escape from a helpless situation at home, time to spare, but also being grateful for life.

The results obtained in the study conducted by B. Andersson et al. and S. Brown et al., in which they found that altruistic motivation was a reliable predictor of remaining in voluntary service (Andersson et al. 2005, pp. 602-609; Brown al al. 2012, pp. 87-96) were also confirmed in the study. The findings of other studies which stated that important motives in hospice voluntary service were the ones connected with moral values and spirituality (Winterich et al. 2013, pp. 759-770; Silverberg Koerner et al. 2013, pp. 95-111) were likewise reflected in the study presented in this article.

\section{Conclusions}

In the process of recruiting volunteers for hospice service, it is worth remembering that the lack of motivation for this kind of service is not a good sign. Negative correlation between the length of service and the initial lack of motivation confirms that people who come to a hospice not knowing why they do it, do not stay there long. And statistically significant positive correlation between the length of service and altruistic motivation (a desire to do something more for others) indicates that it is a good predictor of remaining in a hospice for longer.

Reading about motivation of the first volunteers in St. Lazarus' Hospice in Cracow one might experience a kind of sorrow or pity that it has disappeared. The founders of the first hospices are now passing away and taking the first enthusiasm with them. This change in motivation of hospice volunteers is a sign of the times, as today hospices become institutions. However, even today there are volunteers who understand these first ideas, and maybe they will become the seeds of renewal. They might also trigger the development of a positive educational spirit in voluntary teams. This, of course, requires a wise selection of team coordinators, people who will be able to spot those who will inspire and enthuse others. In order to achieve this goal, however, it is worth remembering the words of E. Bodek, who said that a hospice "is not a hospital, not a shelter, but Home." And home is also the environment where education takes place.

\section{References}

Andersson B, Ohlen J. (2005), Being a hospice volunteer, Palliative Medicine, no 19, p. 602-609.

Bodek E. (2009), Rola wolontariusza $w$ domu chorego, na oddziale stacjonarnym i dziennym. In: Materiały dla wolontariuszy. Towarzystwo Przyjaciół Chorych "Hospicjum im. św. Łazarza" in Kraków, Kraków: TPCh "Hospicjum św. Łazarza”, pp. 16-21. 
Brown S., Konrath S., Fuhrel-Forbis A., Lou A. (2012), Motives for Volunteering Are Associated With Mortality Risk in Older Adults, Health Psychology, no 1(31), pp. 87-96.

De Walden-Gałuszko K. (2004), Filozofia postępowania w opiece paliatywnej. In: Podstawy opieki paliatywnej. Ed. K. de Walden-Gałuszko. Warszawa: Wydawnictwo Lekarskie PZWL. pp. 11-19.

De Walden-Gałuszko K. (1997), Historia idei hospicjum i opieki - opieka psychopaliatywna, in: Przed przejściem, ed. D. Śpiewakowska, R. Szpakowski, Warszawa: Wydawnictwo Salezjańskie, pp. 57-63.

Finkelstein M. A. (2008), Volunteer satisfaction and Volunteer action: a functional approach, Social Behavior and Personality, no. 1(36), pp. 9-18.

Gasiul H. (2002), Teorie emocji i motywacji. Rozważania psychologiczne. Warszawa: Wydawnictwo UKSW.

Górecki M. (2000), Hospicjum w służbie umierających. Warszawa: Wydawnictwo Akademickie "Żak".

Górecki M. (2010a), Geneza i rozwój opieki hospicyjnej-paliatywnej, in: Prawda umierania i tajemnica śmierci, ed. M. Górecki, Warszawa: Wydawnictwo Akademickie “Żak”, pp. 226-257.

Górecki M. (2010b), Przesłanie ideowe i instytucjonalizacja wspomagania umierających, in: Prawda umierania i tajemnica śmierci, ed. M. Górecki, Warszawa: Wydawnictwo Akademickie Żak, s.203-225.

Górecki M. (2016), Wolontariat seniorów i dla seniorów, in: Obiektywny i subiektywny wymiar starości, ed. E. Dubas, M. Muszyński, Łódź: Wydawnictwo Uniwersytetu Łódzkiego, pp. 91-102.

Górecki M. (2013), Wolontariat w organizacjach pozarządowych w Polsce, Pedagogika społeczna, no 2(48), pp. 89-114.

Grudziński A. (2013), Rola opieki paliatywno-hospicyjnej w pomocy osobom terminalnie chorym, in: Człowiek wobec bólu, cierpienia i śmierci, ed. J. Stal, N. Braven, Kraków: Wydawnictwo Naukowe UPJPII, pp. 207-217.

In Solidarity. Hospice-Palliative Care in Poland, ed. A. Janowicz, P. Krakowiak, A. Stolarczyk (2015), Gdańsk: Fundacja Hospicyjna Hospicjum to też życie.

Krakowiak P. (2011), Praca socjalna u kresu życia na świecie i możliwości jej rozwoju w Polsce, Piel. Zdr. Publ. No 1(3), pp. 245-250.

Krakowiak P. (2012), Wolontariat w opiece u kresu życia. Geneza, rozwój funkcjonowanie, możliwości optymalizacji i integracji. Ku syntezie socjopedagogicznej, Toruń: Wydawnictwo Naukowe Uniwersytetu Mikołaja Kopernika.

Krakowiak P. (2007), Zarys historii ruchu hospicyjnego na świecie $i w$ Polsce. Chrześcijańskie i humanistyczne przesłanki opieki hospicyjnej, in: Ksiadz Eugeniusz Dutkiewicz SAC. Ojciec ruchu hospicyjnego w Polsce, ed. P. Krakowiak, A Stolarczyk, Gdańsk: Biblioteka Fundacji Hospicyjnej, pp. 195-248. 
Krakowiak P., Janowicz A. (2008), Historia i współczesność wolontariatu hospicyjnego, in: Podręcznik koordynatora wolontariatu hospicyjnego, ed. P. Krakowiak, A. Modlińska, J. Binnebeselt, Gdańsk: Biblioteka Fundacji Hospicyjnej, pp. 1-24.

Krakowiak P., Janowicz A., Modlińska A. (2008), Przegląd programów szkoleniowych dla wolontariuszy realizowanych $w$ ośrodkach paliatywno-hospicyjnych, in: Podrecznik koordynatora wolontariatu hospicyjnego, ed. P. Krakowiak, A. Modlińska, J. Binnebeselt, Gdańsk: Biblioteka Fundacji Hospicyjnej, pp.115-150.

Krakowiak P., Kabasiński K., Płodziszewska E., Stachowska B., Kaczkowski J., Modlińska A., Bohdan Z. (2008), Formy wolontariatu hospicyjnego, in: Podręcznik koordynatora wolontariatu hospicyjnego, ed. P. Krakowiak, A. Modlińska, J. Binnebeselt, Gdańsk: Biblioteka Fundacji Hospicyjnej, pp. 25-74.

Krakowiak P., Janowicz A. (2013), Wolontariat $i$ wsparcie opieki nieformalnej sposobami na redukcje cierpienia totalnego osób u kresu życia i ich bliskich, in: Ból i cierpienie. Ujęcie interdyscyplinarne. Żyć godnie do końca. Vol. 4, ed. Krzyżanowski D. M., Payne M., Fal A. M., Wrocław: Wyd. Presscom, pp. 219-246.

Krakowiak P. (2007), Zarys historii ruchu hospicyjnego na świecie i w Polsce. Chrześcijańskie i humanistyczne przesłanki opieki hospicyjnej, in: Ksiądz Eugeniusz Dutkiewicz SAC. Ojciec ruchu hospicyjnego w Polsce, ed. P. Krakowiak SAC, A. Stolarczyk. Gdańsk: Biblioteka Fundacji Hospicyjnej, pp. 195-248.

Omoto A. M., Snyder M., Martino S. C. (2000), Volunteerism and the Life Course: Investigating Age-Related Agendas for Action, Basic and Applied Social Psychology, no 3(22), pp. 181-197.

Przewłocka J. (2011), Zaangażowanie społeczne Polaków w roku 2010: wolontariat, filantropia, 1\%. Raport z badań. Warszawa: Stowarzyszenie Klon-Jawor.

Silverberg Koerner S., Shirai Y., Pedrozo R. (2013), Role of Religious/Spiritual Beliefs and Practices Among Latino Family Caregivers of Mexican Desent, Journal of Latina Psychology, no 1(2), pp. 95-111.

Public Benefit and Volunteer Work Act of 24.04.2003 Journal of Laws of 2003 no 96, item 873, as amended (Ustawa $z$ dnia 24.04.2003 r. o działalności pożytku publicznego i o wolontariacie. Dz. U. z 2003 r., Nr. 96, poz. 873 z późn. zm.).

Weber T. (2009), Oswajanie umierania. Kraków: Wydawnictwo FALL.

Winterich K. P., Agnino K., Mittal V., Swartz R. (2013), When Moral Identity Symbolization Motivates Prosocial Behavior: The Role of Recogniton and Moral Identity Internalization, Journal of Applied Psychology, no 5(98), pp. 759-770.

\section{MOTYWACJE WOLONTARIUSZY HOSPICYJNYCH DAWNIEJ I DZISIAJ}

Streszczenie: Powstanie pierwszego hospicjum w Polsce jest związane ze stosunkowo niedawną historią lat 7o. Jednak zmiany, jakie się dokonały w Polsce w ostatnich latach, powodują, że dzisiaj na wolontariat hospicyjny decydują się inne osoby niż ponad 40 lat 
temu. Artykuł pokaże wpierw, jak wyglądały idee wolontariatu hospicyjnego. Zostanie to opisane w świetle wywiadu z byłą koordynator wolontariatu w Hospicjum św. Łazarza w Krakowie, Ewą Bodek. Wywiad ten jest obecnie przygotowywany do publikowania. Jak wygląda motywacja wolontariuszy dzisiaj, zostanie zaś przedstawione w świetle analizy rozmów wstępnych z czterech ostatnich rekrutacji kandydatów na wolontariuszy Hospicjum św. Łazarza w Krakowie. Nowością artykułu będzie zestawienie z jednej strony wyników badań jakościowych dotyczących motywacji pierwszych hospicyjnych wolontariuszy w Polsce, $z$ drugiej zaś wyników analizy badań dotyczących motywacji przychodzących w ostatnich latach do hospicjum kandydatów do wolontariatu.

Słowa kluczowe: wolontariat, motywacja, hospicjum.

Anna Seredyńska - dr nauk społecznych, psycholog-psychoterapeuta, pedagog, adiunkt w Katedrze Psychopedagogiki Instytutu Nauk o Wychowaniu Wydziału Pedagogicznego Akademii Ignatianum w Krakowie. Zainteresowania badawcze: psychoterapia psychodynamiczna, psychopatologia, wypalenie zawodowe pedagogów, superwizja koleżeńska pedagogów, wolontariat hospicyjny. Publikacje monograficzne: Mechanizmy obronne $w$ diagnozie psychologicznej i pedagogicznej (Kraków 2015), Od zaburzeń zachowania do zaburzeń osobowości (Kraków 2016), Mechanizmy obronne jako wskaźnik stylu osobowości. Charakterystyka psychometryczna narzędzia badawczego (Kraków 2016). Adres e-mailowy: asered@interia.pl. 